\title{
Effect of Zearalenone Administrated at Late Gestation Days on Fertility of The F-1 Offspring in Swiss webster (Mus musculus)
}

\author{
Efecto de la Zearalenona Administrada los Días Finales de Gestación sobre \\ la Fertilidad de las Crías F-1 en Ratones Swiss Webster (Mus musculus)
}

\author{
Yulia Irnidayanti
}

IRNIDAYANTI, Y. Effect of zearalenone administrated at late gestation days on fertility of the F-1 offspring in Swiss webster (Mus musculus). Int. J. Morphol., 30(3):1197-1202, 2012.

SUMMARY: Zearalenone solution was given to dams mice subcutaneously at a dose of $30 \mathrm{mg} / \mathrm{kg}$ body weight at the age of pregnancy 13 to 18 days. Control mice were given only sesame oil. Furthermore, dams mice were allowed to deliver their litter and pups were weaned on 21 days of age. The live birth index and viability of the F-1 offspring were recorded. Determination of fertility of the F-1 offspring were undertaken by mating interlitters. On days 18 of gestation, the F-1 offspring were killed by cervical dislocation. The observation was performed on the number of live or dead fetus, embryo resorption, the number of implantation and the percentage of gestation loss. The result revealed that administration of zearalenone on days 13 to 18 of gestation caused a significant decreasein the number of implantation as the result of mating between control male with treated female and treated male with tretaed female of the F-1 offspring. It could be concluded that in the F-1 offspring, zearalenone interfered the process of ovarian develoment, stimulated the differentation of the uterus, decreased the fertility of the female and the effect of zearalenon was more persistent in the female than in the male

KEY WORDS: Zearalenone; Fertilitas indeks; Gestation indeks; Number of implantation; Persistent.

\section{INTRODUCTION}

Zearalenone is a natural mycotoxin produced by Fusarium roseum and grow on grain stored in a state of very high humidity (Chang et al.,1979). Secondary metabolites produced by Fusarium $s p$, associated with hiperestrogenisme syndrome and bleeding in farm animals (Mirocha et al., 1976). Mycotoxin has a trivial name, zearalenone and its trade name RAL (b-resorcylic acid lactone). Initial information about the chemical structure zearalenone expressed as enatiomorf of 6-(10-hydroxy-6oxo-trans-1-undecenyl)-b-resorcylic acid lactone, with chemical formula $\mathrm{C} 18 \mathrm{O} 5 \mathrm{H} 22$. zearalenone can absorb ultraviolet light with wavelengths of 314,274 , and $236 \mathrm{~mm}$, melting point $163-165^{\circ} \mathrm{C}$, with molecular weight 318 and have the character of blue-green fluorescence (Mirocha et al., 1967).

The results Bennett \& Shotwell (1979) states that "barley" which contaminated by Fusarium, when consumed by pigs can cause stillbirth, death of child at birth, reduced the size of puppies, and decreasing egg production. Based on the results of Chang et al., that the presence of estrogenic syndrome in children who are breast- feeding pigs, associated with the passing of toxins in breast milk. Report the results of Kiesseling \& Pettersson (1978) suggests that secondary metabolites that cause estrogenic syndrome, such as bleeding of part vulvar and vaginal posterior, associated with consumption of moldy food. Zearalenone metabolism in the body occurs in the liver, through two different pathways. First, the conjugate with glucuronic acid, because by adding UDPGA (Uridine diphosphate Glucuronic Acid), then the number a conjugate zearalenone with glucuronic acid increased. Second, through the reduction zearalenon to zearalenol, probably catalyzed by hydroxysteroid.

Preliminary information about the chemical structure is expressed as enatiomorf zearalenone of 6 - (10hydroxy-6-oxo-trans-1-undecenyl) - b-resorcylic acid lactone, with the chemical formula $\mathrm{C} 18 \mathrm{O} 5 \mathrm{H} 22$. Zearalenone nature is absorbing ultraviolet light with wave lengths 314,274 , and $236 \mathrm{~mm}$, the melting point of 163 $165^{\circ} \mathrm{C}$, with molecular weight 318 and are bluegreen fluorescence (Mirocha et al., 1967). Although 
zearalenone not have chemical structures such as steroids, but this substance has uteotropik potent activity in some animals (Ueno et al., 1974). Unique chemical structure of zearalenone can interact directly with estrogen receptors in the body and give rise to biological and biochemical responses such as those caused by natural estrogen, estradiol (Katzenellenbogen et al., 1979). Zearalenone is a naturally occurring mycotoxin produced by Fusarium roseum and grow on grain stored in a state of very high humidity. Corn, a component of animal feed, which have a high risk of mold growth. Therefore, when the feed consumed by livestock may affect the differentiation and development of the fetal reproduction system in cattle. Based on the above information, then do research to find out whether zearalenone affect the ability of life and fertility of the F-1 generation mice.

\section{MATERIAL AND METHOD}

Animals used in these experiments were mice (Mus musculus) Swiss Webster derived from laboratory animal house, Department of Pharmacy ITB. Furthermore, animals kept in cages, Department of Biology, ITB. Male and female mice were kept in separate cages. Each virgin female mice that were in a state of estrus, aged 11-12 weeks with body weight from 23.5 to $29.5 \mathrm{~g}$ were mated with male mice of the same age. Mating of male mice with females performed at 17.00. The existence of vaginal plug the next morning is a sign of copulation and indicates at gestation day zero. Then the female mice are weighed and separated from the male.

Zearalenone used in this study, derived from Makor Chemical POB 6570, Jerusalem Israel. Zearalenone crystals dissolved in sesame oil. Zearalenone solution injected daily, subcutaneously in mice at gestation 13 to 18 days. The volume of injection for the control and treated mice was 0.1 $\mathrm{ml} / 10 \mathrm{~g}$ body weight, with a dose of $30 \mathrm{mg} / \mathrm{kg}$ body weight. Control mice were only given sesame oil.

Staining of the implantation site is done by dissecting the uterus and then dropped with a solution of $0.5 \%$ ammonium sulfide for 10 minutes calculation is then performed live births Index (Manson \& Kang, 1989) is number of pups born alive per number of implantations at times $100 \%$. Recording done also to the number of live and dead mice generation F-1 at birth, number of pups living mice on post natal (PN) -1, PN-4 and PN-21. To calculate the perinatal mortality index is the number of pups born die divided by the number of pups born multiplied by $100 \%$, while viability index on PN-4 is the number of pups living in the PN-4 divided by the number of pups living in the PN-0 multiplied by $100 \%$ (Weil et al., 1972). Determination of fertility of the F-1 offspring were undertaken by mating interlitter.Mating patterns consisted

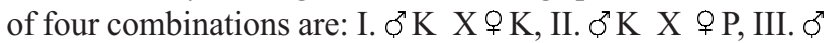
$\mathrm{PX}$ 우 K, IV. $\sigma \mathrm{P}$ X 우 P. Each group consists of 10 mating pairs of mice. At the age of 18 days of pregnancy, all F-1 generation mice were killed by cervical dislocation, and then calculated the number of females that were pregnant. The "Wilcoxon's rank sum test" is used to compute nonparametric data, among others: viability index, index mortality of perinatal, weaning index, live birth index and the percentage loss of gestation. For the index gestation and fertility index used testing "Chi Square" (Zar, 1984).

\section{RESULTS AND DISCUSSION}

Result of performance on the mice dams of body weight are listed in Table I. Average body weight

Table I. The body weight of mice dams Mus musculus (Swiss Webster) administrated zearalenone at a dose of $30 \mathrm{mg} / \mathrm{kg}$ body weight at gestation days 13 to 18 .

\begin{tabular}{llllll}
\hline Gestation days (GD) & $\begin{array}{l}\text { Dose Zearalenone } \\
(\mathrm{mg} / \mathrm{kg} \mathrm{bw})\end{array}$ & $\begin{array}{l}\text { Number } \\
\text { of dams }\end{array}$ & $\begin{array}{l}\text { Weight body } \\
\text { of dams at GD-0 } \\
(\mathrm{g}) \mathrm{X} \pm \mathrm{Sem}\end{array}$ & $\begin{array}{l}\text { Weight body } \\
\text { of dams at GD-18 } \\
(\mathrm{g}) \mathrm{X} \pm \mathrm{Sem}\end{array}$ & $\begin{array}{l}\text { Added of body weight } \\
\text { in dams at GD-18 } \\
(\mathrm{g}) \mathrm{X} \pm \mathrm{Sem}\end{array}$ \\
\hline \multirow{2}{*}{$13 \mathrm{~s} / \mathrm{d} 18$} & 0 & 10 & $26.18 \pm 0.44$ & $44.04 \pm 1.29$ & $18.17 \pm 0.66$ \\
& 30 & 10 & $27.86 \pm 0.59$ & $46.07 \pm 1.35$ & $18.21 \pm 0.96$ \\
\hline
\end{tabular}

Table II. The condition of F-1 offspring from the dams, who was administrated zearalenone with a dose of $30 \mathrm{mg} / \mathrm{kg}$ body weight at gestation days 13 to 18 .

\begin{tabular}{lccccc}
\hline $\begin{array}{l}\text { Gestation days } \\
(\mathrm{GD})\end{array}$ & $\begin{array}{c}\text { Dose } \\
\text { Zearalenone } \\
(\mathrm{mg} / \mathrm{kg} \mathrm{bb})\end{array}$ & $\begin{array}{c}\text { Number } \\
\text { of dams }\end{array}$ & $\begin{array}{c}\text { Average of fetus live } \\
\text { X } \pm \text { Sem (total) } \\
\text { A }\end{array}$ & $\begin{array}{c}\text { Live birth Indeks } \\
\text { X } \pm \text { Sem } \\
\text { A/B x 100\% }\end{array}$ & $\begin{array}{c}\text { Number of implantation } \\
\text { Average X } \pm \text { Sem (total) } \\
\text { B }\end{array}$ \\
\hline 13 s/d 18 & 0 & 10 & $8.60 \pm 0.60(86)$ & $88.07 \pm 4.25$ & $9.80 \pm 0.53(98)$ \\
& 30 & 10 & $6.50 \pm 1.13(65)$ & $67.41 \pm 11.04$ & $9.90 \pm 0.59(99)$ \\
\hline
\end{tabular}




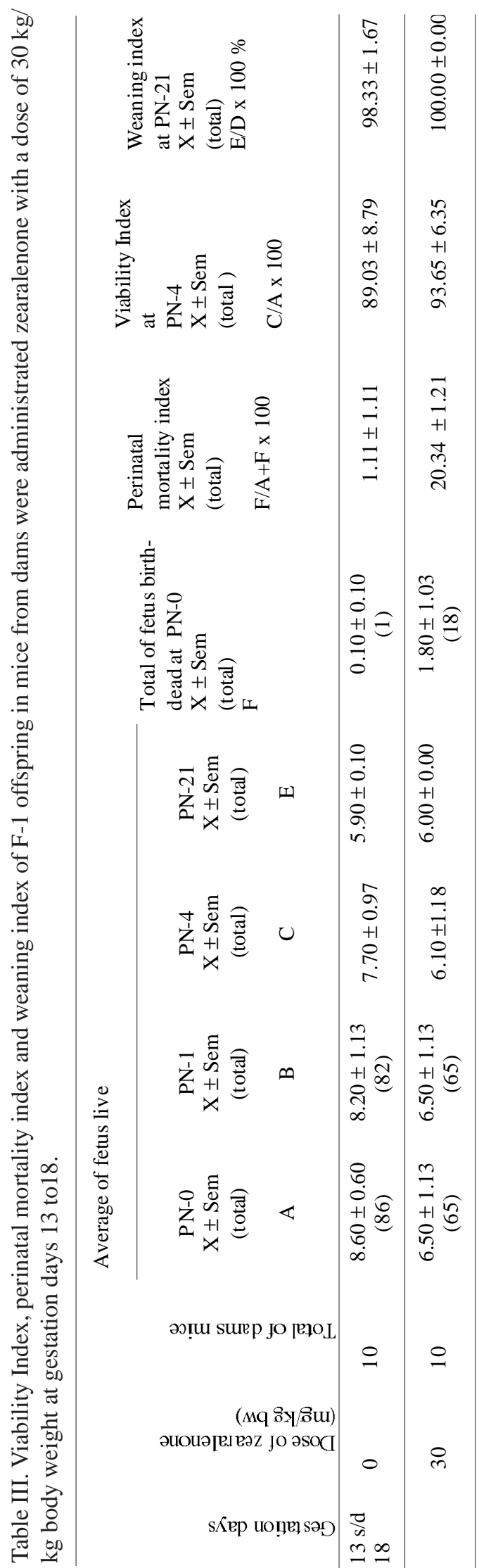

and increase of body weight did not differ from the control treatment. Thus, applying the zearalenone with the doses used in this study on mice that were dams not to be toxic, because it does not lose weight. Average number of puppies born in the treated group tendency to decrease Therefore, live birth index also tendency to be lower than with controls (Table II). This is caused by a number of stillborn pups is higher than the control. Presumably that zearalenone can cause pups mortality of mice at birth. This situation is supported by the research results of Kurtz et al. (1969), Chang et al. and Berger et al. (1981), that administration zearalenone or mouldy corn to swine cause a reduction in the size of pups.

Increasing in body weight of male and female mice F1 generation began obviously each on $\mathrm{PN}-7$ and $\mathrm{PN}-4$ compared with controls. This indicates that there is not interruption in the process of metabolism (Collins, 1977), because the state is always indicated by higher average body weight male and female mice from generation F-1 on PN-0 to PN-21 as compared than controls. This is showing that zearalenone not inhibit the growth of male and female mice from generation F-1 during the period of lactation. Zearalenone influence on the ability of mice generation F-1 to live, can be seen in Table III. Weaning index and viability index on mice treatment from F-1 offspring, although higher than controls, but not significantly. Therefore it can be concluded that seemed zearalenone does not inhibit the ability of live pups mice of generation F-1, during PN-0 to PN- 21. Perinatal mortality index mice F-1 offspring, although statistically not significantly different from controls, but tendency to be higher. It therefore seems zearalenone tendency cause the death of pups. The situation was also supported by the research results of Kurtz et al., Chang et al. and Berger et al., administration feed containing zearalenone in female swine caused the death of pups at birth. Therefore it can be concluded, that zearalenone tendency cause the death of pups at birth.

Fertility index typicallyused to measure the ability to pregnant female mice (Collins). In Table III, shows that the fertility index in mating assay results between treated males with the control females was 90, which tendency to be higher than the control. While the fertility index in mating test results between control males with terated female and treatment males with treated female are 50 and 60 , which tendency to be lower than the control group, with fertility index is 80 . This condition is caused by the mating test results, there are 5 and 4 mice are not pregnant.All mice are not pregnant,after surgery showed abnormalities in ovarian and uterine dilatation. The results are consistent with research was done by Weaver et al. (1986), which states that the administration of $250 \mathrm{mg}$ of pure zearalenone in virgin female pigs, orally causes decrease in conception rate. According to Edgren \& Clancy (1968) and Yasuda et al. (1981), administration ethinylestradiol, in pregnant rats during pregnancy continued, causing a decrease in fertility rate of generation of F-1 mice. It can be concluded, that the administration zearalenone on current research tendency cause a decreased the fertility of the female. The fertility of F-1 offspring in mice also supported by the gestation 
index was always lower in the mating pairs test. It seems zearalenone greater effect on fertility of female mice, because if mated with male treatment and male control, always showed low fertility index and gestation index. This is also supported by the low number of implantation and the high percentage of loss of gestation of mating pairs test between the males control with females treatment and males treated with females treated, which are significant different from the control mating pairs test. Therefore, the decrease of fertility generation F-1 mice is the cause of female mice treated and do not male mice, so it can be concluded that the effect of zearalenone was more persistent in the female than in the male.

Observations on reproduction of mice performance of mice generation F-1, are listed in Table V and Table VI. The number of corpus luteum on mated pairs test beetwen treated males with treated female, were not significanly (12.80 \pm 1.49$)$ than controls group (12.75 \pm 0.56$)$. It can be concluded that zearalenone no effect on the number of eggs ovulation. Percentage loss of gestation on pairs of mated pairs test beetwen control male with treated females, and males treated with treated female were significant, more higher than control group. The lowest of implantation number in a pairs of test mating between control male with treated female, dan treated males with treated females, causing the fetus to live in mating pairs test were significantly lower than controls. From the results of this study concluded that zearalenone not affect ovarian function, because the number of corpus luteum were not significantly from controls in all mating pairs test, but zearalenone affect the function of uterine on F-1 offspring of mice, which disrupt the uterine environment, thus inhibiting implantation. This data supported by the percentage of resorption embryos in the test pair mating between controls male with treated female and treated males with treated females were significantly higher than control group. While the number of dead fetus, which found only in groups of mating pairs test between treated male and treated female, however was not significantly from controls group. Percentage total of intrauterine death on mating pairs test between control males with females treated and males treated with females treatment, more higher than control group. The high percentage of the total intrauterine death in F-1 offspring mice, caused by the high percentage of resorption embryos. This is different with percentage of total intrauterine death in F-1 offspring dams, whrerever caused by fetus death. Thus it can be concluded, that the impact zearalenone administrated to the dams of mice, there is still a real effect on female mice F-1 generation.

Table IV. Fertility index and gestation index of F-1 offspring mice from dams were administrated zearalenone with a dose of $30 \mathrm{~kg} / \mathrm{kg}$ body weight at gestation days 13 to 18 .

\begin{tabular}{|c|c|c|c|c|c|c|}
\hline \multirow{2}{*}{$\begin{array}{l}\text { Pattern of mating } \\
\text { F-1 } \\
\text { Offspring }\end{array}$} & \multirow{2}{*}{$\begin{array}{l}\text { Total of } \\
\text { pregnancy } \\
\text { mice }\end{array}$} & \multicolumn{3}{|c|}{$\%$ total intrauterine mortality } & \multirow{2}{*}{$\begin{array}{l}\text { Fetus live } \\
\% \mathrm{X} \pm \text { sem } \\
\text { (total) }\end{array}$} & \multirow{2}{*}{$\begin{array}{c}\text { Average of } \\
\text { implantation total } \\
x \pm \text { sem }\end{array}$} \\
\hline & & $\begin{array}{c}\text { Resorption embryo } \\
\mathrm{x} \pm \text { sem } \\
\text { (total) }\end{array}$ & $\begin{array}{l}\text { Fetus death (total) } \\
\% \text { intrauterine mortality }\end{array}$ & $\begin{array}{l}\text { Average } \\
\text { (total) }\end{array}$ & & \\
\hline 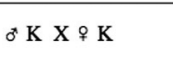 & 8 & $\begin{array}{c}7.02 \pm 3.98 \\
(6)\end{array}$ & $\begin{array}{l}0.83 \pm 2.36 \\
\text { (1) }\end{array}$ & $\begin{array}{c}7.85 \pm 4.06 \\
(7)\end{array}$ & $\begin{array}{c}92.15 \pm 4.06 \\
(90)\end{array}$ & $\begin{array}{c}12.13 \pm 0.61 \\
(97)\end{array}$ \\
\hline 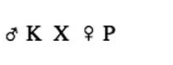 & 4 & $\begin{array}{c}39.09 \pm 12.16^{* *} \\
(11)\end{array}$ & $\begin{array}{l}0.00 \pm 0.00 \\
(0)\end{array}$ & $\begin{array}{c}39.09 \pm 12.16^{* *} \\
(11)\end{array}$ & $\begin{array}{c}60.91 \pm 12.16^{* *} \\
(18)\end{array}$ & $\begin{array}{c}7.25 \pm 1.18^{* *} \\
(29)\end{array}$ \\
\hline * $\mathrm{PX}$ \% $\mathrm{K}$ & 9 & $\begin{array}{c}14.13 \pm 4.41 \\
(15)\end{array}$ & $\begin{array}{c}0.00 \pm 0.00 \\
(0)\end{array}$ & $\begin{array}{c}14.13 \pm 4.41 \\
(15)\end{array}$ & $\begin{array}{c}85.87 \pm 4.41 \\
(82)\end{array}$ & $\begin{array}{c}10.44 \pm 1.21 \\
(97)\end{array}$ \\
\hline ơ $\mathrm{P}$ ๆ $\mathrm{P}$ & 5 & $\begin{array}{c}51.52 \pm 13.93 * * \\
(17)\end{array}$ & $\begin{array}{c}6.22 \pm 4.06 \\
\text { (3) }\end{array}$ & $\begin{array}{c}57.75 \pm 12.01 * * \\
(20)\end{array}$ & $\begin{array}{c}42.25 \pm 12.01 * * \\
(16)\end{array}$ & $\begin{array}{c}7.20 \pm 1.20 * * \\
(36)\end{array}$ \\
\hline
\end{tabular}

Table V. Percentage loss of gestation F-1 offspring from dams were administrated zearalenone with a dose of $30 \mathrm{~kg} / \mathrm{kg}$ body weight at gestation days 13 to 18 .

\begin{tabular}{|c|c|c|c|c|c|c|}
\hline \multirow{2}{*}{$\begin{array}{l}\text { Pattern of mating F-1 } \\
\text { Offspring }\end{array}$} & \multirow{2}{*}{$\begin{array}{c}\text { Total of mating } \\
\text { pairs test }\end{array}$} & \multirow{2}{*}{$\begin{array}{c}\text { Total of } \\
\text { pregnancy } \\
\text { mice }\end{array}$} & \multirow{2}{*}{$\begin{array}{l}\text { Total of corpus } \\
\text { luteum } x \pm \text { sem } \\
\text { (total) (A) }\end{array}$} & \multirow{2}{*}{$\begin{array}{l}\text { Total of implantation } \\
x \pm \text { sem (total) } \\
\text { (B) }\end{array}$} & \multicolumn{2}{|c|}{ \% Loss of gestation } \\
\hline & & & & & Total & $\% \mathrm{x} \pm \operatorname{sem}\{(\mathbf{A}-\mathrm{B}) / \mathrm{A}\}$ \\
\hline ð $\mathrm{K} \mathrm{X}+\mathrm{K}$ & 10 & 8 & $\begin{array}{c}12.75 \pm 0.56 \\
(102)\end{array}$ & $\begin{array}{c}12.13 \pm 0.61 \\
\text { (97) }\end{array}$ & 5 & $4.97 \pm 2.01$ \\
\hline o $\mathrm{K} X$ X $\mathrm{P}$ & 10 & 4 & $\begin{array}{c}11.89 \pm 1.23 \\
(107)\end{array}$ & $\begin{array}{c}7.25 \pm 1.18 * * \\
(29)\end{array}$ & 78 & $65.31 \pm 14.57 * *$ \\
\hline ơ $\mathrm{PX}$ ㅇ $\mathrm{K}$ & 10 & 9 & $\begin{array}{c}12.50 \pm 0.87 \\
(112)\end{array}$ & $\begin{array}{c}10.77 \pm 1.10 \\
(97)\end{array}$ & 15 & $24.29 \pm 10.44$ \\
\hline o $\mathrm{P} X \& \mathrm{P}$ & 10 & 5 & $\begin{array}{c}12.80 \pm 1.49 \\
(64)\end{array}$ & $\begin{array}{c}7.20 \pm 1.20 * * \\
(36)\end{array}$ & 28 & $42.27 \pm 10.85^{* *}$ \\
\hline
\end{tabular}

**significant at $\mathrm{P}<0,01$ than control. 
Table VI. Performance of reproduction of F-1offspring mice from dams were administrated zearalenone with a dose of $30 \mathrm{~kg} / \mathrm{kg}$ body weight at gestation days 13 to 18 .

\begin{tabular}{|c|c|c|c|c|c|c|}
\hline \multirow{2}{*}{$\begin{array}{l}\text { Pattern of } \\
\text { mating F-1 } \\
\text { offspring }\end{array}$} & \multirow{2}{*}{$\begin{array}{l}\text { Total of } \\
\text { mating } \\
\text { pairs test } \\
\text { (A) }\end{array}$} & \multicolumn{3}{|c|}{ Total of female } & \multirow{2}{*}{$\begin{array}{c}\text { Fertility } \\
\text { index } \\
\text { B/A x } \\
100\end{array}$} & \multirow{2}{*}{$\begin{array}{c}\text { Gestation } \\
\text { index } \\
\text { D/B x } 100\end{array}$} \\
\hline & & $\begin{array}{l}\text { pregnancy } \\
\text { (B) }\end{array}$ & $\begin{array}{c}\text { Not } \\
\text { Pregnancy } \\
\text { (C) }\end{array}$ & $\begin{array}{l}\text { Pregnancy } \\
\text { with live } \\
\text { pups (D) }\end{array}$ & & \\
\hline ơ $\mathrm{K} \mathrm{X}$ 우 $\mathrm{K}$ & 10 & 8 & 2 & 8 & 80.00 & 100.00 \\
\hline ơ $\mathrm{K} \mathrm{X}$ \% $\mathrm{P}$ & 10 & 5 & 5 & 4 & 50.00 & 80.00 \\
\hline$\sigma^{0} \mathrm{PX}$ ㅇ $\mathrm{K}$ & 10 & 9 & 1 & 9 & 90.00 & 100.00 \\
\hline ơ $\mathrm{P} \mathrm{X}$ ㅇ $\mathrm{P}$ & 10 & 6 & 4 & 5 & 60.00 & 83.33 \\
\hline
\end{tabular}

**significant at $\mathrm{P}<0.01$ than control.

\section{CONCLUSIONS}

From the results of research has been done today, it can be concluded that zearalenone is not toxic to the dams of mice, tendency to cause the death of the F-1 generation mice at birth, does not affect the ability of mice living F1offspring through PN-21.Zearalenone causes decreased fertility of female mice generation F-1, is embryo toxic to mice F-2 offspring and its effect on female mice of generation F-1 is more persistent than male mice, so that reproduction is impaired.

\section{ACKNOWLEDGMENTS}

The author wishes to thank Prof. Dr. Sri Sudarwati and Dr. Lien A. Sutasurya for helpful comments on the manuscript.

IRNIDAYANTI, Y. Efecto de la zearalenona administrada los días finales de gestación sobre la fertilidad de las crías F-1 en ratones Swiss Webster (Mus musculus). Int. J. Morphol., 30(3):1197-1202, 2012.

RESUMEN: Se administró una solución subcutánea de zearalenona en una dosis de $30 \mathrm{mg} / \mathrm{kg}$ de peso corporal en ratonas preñadas entre 13 a 18 días de gestación. Los ratones control recibieron sólo aceite de sésamo. Además, a las ratonas preñadas se les permitió amamantar a sus crías para ser destetadas a los 21 días de edad. El índice de nacidos vivos y viabilidad de la descendencia F-1 fuer registrado. La determinación de la fertilidad de la descendencia F-1 se llevó a cabo por apareamiento intercrías. El día 18 de gestación, la descendencia F-1 se sacrificó por dislocación cervical. Se observó el número de fetos vivos y muertos, reabsorción del embrión, número de implantaciones y porcentaje de pérdida de gestación. El resultado reveló que la administración de la zearalenona entre los días 13-18 de gestación causó un significativo descenso en el número de implantaciones, como resultado del apareamiento entre machos controles con hembras tratadas y machos tratados con hembras tratadas (F-1 crías). Se puede concluir que en la descendencia F1, la zearalenona interfiere en el proceso de desarrollo ovárico, estimulado la diferenciación del útero, disminuyendo la fertilidad de la hembra; además el efecto del zearalenon fue más persistente en la hembra que en el macho.

PALABRAS CLAVE: Zearalenona; Indice de Fertilidad; Indice de gestación; Número de implantación; Persistencia.

\section{REFERENCES}

Bannett, G. A. \& Shotwell, O. L. Zearalenone in cereal grains. J. Am. Oil Chem. Soc., 56(9):812-9, 1979.

Berger, T.; Esbenshade, K. L.; Diekman, M. A.; Hoagland, T. \& Tuite, J. Influence of prepubertal consumption of zearalenone on sexual development of boars. J. Anim. Sci., 53(6):1559-64, 1981.
Chang, K.; Kurtz, H. J. \& Mirocha, C. J. Effects of the mycotoxin zearalenone on swine reproduction. Am. J. Vet. Res., 40(9):1260-7, 1979.

Collins, T. F. X. Multigeneration reproduction studies. In: Handbook of teratology. Wilson, J. G. \& Fraser, F. C. (Eds.). Vol 4. New York-London, Plenum Press, 1977. pp.205-7. 
Edgren, R. A. \& Clancy, D. P. The effects of norgestrel, ethinyl estradiol, and their combination (ovral) on the young of female rats treated during pregnancy. Int. J. Fertil., 13(3):209-14, 1968.

Katzenellenbogen, B. S.; Katzenellenbogen, J. A. \& Mordecai, D. Zearalenones: characterization of the estrogenic potencies and receptor interactions of a series of fungal beta-resorcylic acid lactones. Endocrinology, 105(1):33-40, 1979.

Kiessling, K. H. \& Pettersson, H. Metabolism of zearalenone in rat liver. Acta Pharmacol. Toxicol. (Copenh.), 43(4):285-90, 1978.

Kurtz, H. J.; Nairn, M. E.; Nelson, G. H.; Christensen, C. M. \& Mirocha, C. J. Histologic changes in the genital tracts of swine fed estrogenic mycotoxin. Am. J. Vet. Res., 30(4):551-6, 1969.

Manson, J. \& Kang, Y. Test methods for assessing female reproductive and developmental toxicity. In: Hayes, A. (Ed.). Principles and Method of Toxicology. New York, Raven Press, 1989. pp.336-52.

Mirocha, C. J.; Christensen, C. M. \& Nelson, G. H. Estrogenic metabolite produced by Fusarium graminearum in stored corn. Appl. Microbiol., 15(3):497-503, 1967.

Mirocha, C. J.; Pathre, S. V.; Schauerhamer, B. \& Christensen, C. M. Natural occurrence of Fusarium toxins in feedstuff. Appl. Environ. Microbiol., 32(4):553-6, 1976.

Ueno, Y.; Shimada, N.; Yagasaki, S. \& Enomoto, M. Toxicological approaches to the metabolites of Fusaria. VII. Effects of zearalenone on the uteri of mice and rats. Chem. Pharm. Bull. (Tokyo), 22(12):2830-5, 1974.

Weil, C. S.; Woodside, M. D.; Carpenter, C. P. \& Smith, H. F. Jr. Current status of tests for Carbaryl for reproductive and teratogenic effect. Toxicol. Appl. Pharmacol., 21:390-404, 1972.

Weaver, G. A.; Kurtz, H. J.; Behrens, J. C.; Robison, T. S.; Seguin, B. E.; Bates, F. Y. \& Mirocha, C. J. Effect of zearalenone on the fertility of virgin dairy heifers. Am. J. Vet. Res., 47(6):13957, 1986.

Yasuda, Y.; Kihara, T. \& Nishimura, H. Effect of ethinyl estradiol on development of mouse fetuses. Teratology, 23(2):233-9, 1981.

Zar, H. J. Biostatistical analysis. New Jersey, Prentice Hall Inc., 1984. pp.177-9, 200-1.

\author{
Correspondence to: \\ Yulia Irnidayanti \\ Biology Departement \\ Jakarta State of University \\ Faculty of Mathematic and Science \\ Pemuda No. 10 street \\ Jakarta \\ INDONESIA
}

\section{Email: irnidayanti@yahoo.com irnidayanti@unj.ac.id}

Received: 22-01-2012

Accepted: 06-03-2012 